\title{
Macro-aspartate aminotransferase in a healthy woman
}

\author{
Maria Lorubbio', Agostino Ognibene', Benedetta Salvadori', Alessandra Fanelli', and Giacomo Laffi ${ }^{2}$ \\ ${ }^{1}$ General Laboratory, Laboratory Department Careggi Hospital, Florence; ${ }^{2}$ Department of Experimental and Clinical Medicine, Univer- \\ sity of Florence, Florence, Italy
}

\section{Dear Editor,}

An increase in serum aspartate aminotransferase (AST) may be related to different conditions, including viral hepatitis, alcoholic liver disease, cirrhosis, cholestatic syndromes, acute myocardial infarction, or skeletal muscle trauma.' Chronic and isolated elevation of AST in patients with no related clinical signs or symptoms is suggestive for the presence of macro-aspartate aminotransferase (macroAST). ${ }^{2}$ MacroAST is a macroenzyme that circulates in the bloodstream as a high molecular weight complex, either by self-polymerisation or by association with serum proteins such as immunoglobulins (Ig). ${ }^{1}$ The formation of this complex, particularly with $\mathrm{lg}$, may lead to increased activity and/or reduced inactivation, clearance or excretion. ${ }^{1,3}$ Below is a case report of a healthy woman with elevated AST levels due to the presence of macrOAST.

A 45-year-old female was admitted to the gastroenterology department of Careggi Hospital in Florence, because of an isolated increase in AST levels. Family history was positive for arterial hypertension and stroke. The patient had a body mass index of 22.0, and her clinical history showed that she had an ovarian cyst 5 years ago and had taken oral contraceptives from the age of 18 to 35 years. No major findings were present at clinical examination.

Abdominal ultrasound did not reveal any alterations, except for a newly formed ovarian cyst on the left side. The electrocardio- gram did not show any abnormalities. Blood tests at admission showed: AST $149 \mathrm{U} / \mathrm{L}$ (reference interval, 15-37); alanine aminotransferase $19 \mathrm{U} / \mathrm{L}$ (reference interval, 12-65); creatine phosphokinase $95 \mathrm{U} / \mathrm{L}$ (reference interval, 21-215); haptoglobin $1.01 \mathrm{~g} / \mathrm{L}$ (reference interval, $0.3-2$ ); troponin I $<0.015 \mu \mathrm{g} / \mathrm{L}$ (reference interval, $0-0.09$ ); myoglobin $42 \mathrm{ng} / \mathrm{mL}$ (reference interval, 14-106); and creatine kinase-MB $0.7 \mathrm{ng} / \mathrm{mL}$ (reference interval, 0.5-3.6). The levels of lactate dehydrogenase and aldolase were also normal. Diagnostic testing for thyroid disease, muscle disorders, haemolysis and coeliac disease was negative. Serology of viral hepatitis B, C, A, Epstein-Barr virus, cytomegalovirus, and human immunodeficiency virus was also negative. ${ }^{4}$ Values of the subsequent laboratory investigations were constant and varied only slightly over time. All other haematological and biochemical parameters were normal. Presence of macroAST was hypothesised by the gastroenterologist and the clinical laboratory was asked to perform additional tests to confirm this diagnosis.

For the detection of macroAST, the polyethylene glycol (PEG) precipitation method was used by the clinical laboratory as for the evaluation of macroprolactin. ${ }^{5}$ Here, $200 \mu \mathrm{L}$ of serum was added to an equal volume of PEG 6000 (Merck, Milano, Italy) $250 \mathrm{~g} / \mathrm{L}$ in distilled water, vortex-mixed for 1 minute and centrifuged at $1,500 \mathrm{rpm}$ for 30 minutes at $4^{\circ} \mathrm{C}$, resulting in a clear supernatant with a precipitate at the bottom. The PEG solution was prepared fresh every 3 months and stored at $4^{\circ} \mathrm{C} .{ }^{5}$ Simultaneously, $100 \mu \mathrm{L}$

\section{Abbreviations:}

AST, aspartate aminotransferase; Ig, immunoglobulins; macroAST, macroaspartate aminotransferase; PBS, phosphate-buffered saline; PEG, polyethylene glycol

\section{Corresponding author : Maria Lorubbio}

General Laboratory, Laboratory Department Careggi Hospital, Largo Brambilla 3, Florence 50134, Italy

Tel: +39-3207709190, Fax: +39-0575255237

E-mail: lorubbiomaria@gmail.com

https://orcid.org/0000-0003-2786-0994 
Maria Lorubbio, et al.

of serum was mixed with $100 \mu \mathrm{L}$ phosphate-buffered saline (PBS). AST activities were measured both on the supernatant and on the PBS dilution with a Siemens VISTA Clinical Chemistry System (Siemens Healthcare, Milano, Italy) and were adjusted with a correction factor of two for the dilution in the preparation. AST recovery was derived as a percentage of the AST activity measured in the supernatant relative to that measured in the PBS dilution. ${ }^{6}$ To evaluate the effect of PEG precipitation, a serum sample of a patient previously diagnosed with hepatopathologic disease and negative for macroAST was selected and treated in the same way as the clinical case serum sample.

Table 1 shows AST activity after PEG precipitation in the patient from the case report and in the control patient. A recovery of AST activity $\leq 40 \%$ in cases of suspected macroAST indicates the presence of Ig-AST complexes, while this condition is very unlikely at values of AST recovery $>50 \%$. ${ }^{5}$ The use of PEG at defined concentrations has the effect of subtracting the solvents, and the subsequent precipitation of proteins such as $\mathrm{lg}$ and the complexes formed by them, thus measuring the remaining activity in the supernatant. ${ }^{7}$ If macroAST is present, the activity of the enzyme after PEG precipitation is decreased compared to the control. Given this case report finding, the results are consistent with a diagnosis of macroAST and confirm the clinical suspicion. Figure 1 shows how the AST changed from 30, 10 days before diagnosis and during follow-up at 10, 30, and 120 days after diagnosis.

Recently, reports about this disease are increasing; Table 2 collects the macroAST literature previously reported, comparing similarities and differences of each case report. The presence of macrOAST can be determined, as shown in Table 2, by laboratory techniques including gel filtration chromatography, ultrafiltration, immunofixation electrophoresis, Ig depletion using protein $A$ and $G$, refrigerated sample storage for $3-6$ days at $4^{\circ} \mathrm{C}$ and PEG precipitation. In gel filtration chromatography, the molecules are separated according to their size and shape. In this method, the stationary phase is made up of spheres of hydrated material, containing pores that can be crossed only by molecules with certain dimensions. In this way, molecules with dimensions that are too large will cross the column very quickly and be eluted into a smaller volume than the molecules that enter the pores instead. Ultrafiltration is based on the molecular weight of macroAST for separation. It is performed using centrifugal filter units with membranes, and AST activity is measured in the ultracentrifugate after centrifugation for 18 hours. 'Ultracentrifugation and gel filtration chromatography, which constitute the standard reference method, require highly specialised chromatography, are complex, relatively expensive, and time-consuming and are not available in most clinical laboratories. ${ }^{8}$ Electrophoresis for immunofixation with AST staining consists of the electrophoresis of serum proteins using the $\lg G, \lg A$ and $\lg M$ antisera. It allows the nature of enzyme immune complexes to be clarified, but requires high specialisation skills. ${ }^{9}$ For the Ig depletion method using protein $A$ and $G$, instead, proteins $A$ and $G$ are recombinant bacterial proteins used to remove Ig and Ig-AST complexes after incubation with the patient's serum. AST is determined in the supernatant after centrifugation of the sample. The protein $A$ and $G$ method is straightforward and provides unambiguous results, but this method is more expensive and probably only detects AST-IgG macrocomplexes.' Moreover, refrigerated sample storage for $3-6$ days at $4^{\circ} \mathrm{C}$ determines the gradual precipitation of the enzyme-lg complex. This method is simple and reliable, but it is performed over a long time

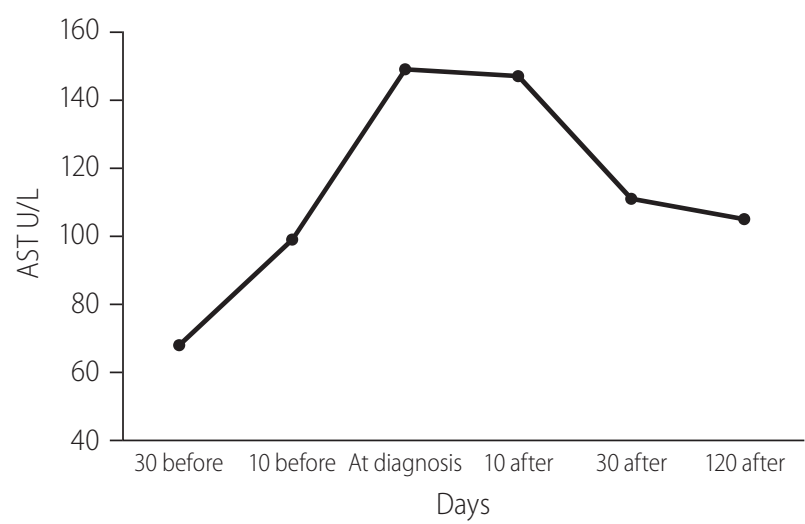

Figure 1. The AST changes: $68 \mathrm{U} / \mathrm{L}, 99 \mathrm{U} / \mathrm{L}$ at 30,10 days before diagnosis, $149 \mathrm{U} / \mathrm{L}$ at diagnosis and $147 \mathrm{U} / \mathrm{L}, 111 \mathrm{U} / \mathrm{L}, 105 \mathrm{U} / \mathrm{L}$ during follow-up at 10, 30, and 120 days after diagnosis respectively. AST, aspartate aminotransferase.

Table 1. AST activity

\begin{tabular}{lcccc} 
& Serum AST (U/L) & PEG AST (U/L)* & PBS AST (U/L)* & AST \% recovery \\
\hline Case & 149 & 8 & 143 & 5.6 \\
Control & 338 & 262 & 270 & 97
\end{tabular}

AST, aspartate aminotransferase; PEG, polyethylene glycol; PBS, phosphate-buffered saline.

*The results are multiplied by the dilution factor 2 . 


\section{CLINCAL and MOLECULAR}

Table 2. Similarities and differences of case reports regarding macroAST

\begin{tabular}{|c|c|c|c|c|c|}
\hline Study & Age & Sex & Country & Clinical features & Diagnostic analytical method \\
\hline van Wijk et al. ${ }^{1}$ (2016) & 50 & $\mathrm{~F}$ & China & $\begin{array}{l}\text { Hypertension, hypertriglyceridemia, } \\
\text { pre-diabetes mellitus, HBV; occasional } \\
\text { muscle aches in right shoulder and legs. } \\
\text { Taking statin. }\end{array}$ & $\begin{array}{l}\text { Ig depletion using protein A } \\
\text { and G; PEG precipitation and } \\
\text { ultrafiltration }\end{array}$ \\
\hline Wener et al. ${ }^{3}$ (2012) & 34 & $\mathrm{~F}$ & Poland & $\begin{array}{l}\text { Severe abdominal and pelvic trauma, } \\
\text { nephrolithiasis, benign ovarian cyst; pain } \\
\text { in the right upper abdomen; no fever. } \\
\text { Occasional intake of antacid. }\end{array}$ & PEG precipitation \\
\hline Lee et al.. (2011) & 25 & $\mathrm{~F}$ & USA & $\begin{array}{l}\text { Paternal dyslipidemia; older brother with } \\
\text { thyroid cancer. Mild fatigue. Occasional } \\
\text { intake of FANS. }\end{array}$ & PEG precipitation \\
\hline Patteet et al. ${ }^{6}$ (2012) & 27 & $\mathrm{~F}$ & Belgium & Migraine treated with topiramate. Tiredness. & PEG precipitation \\
\hline Bustamante et al.' (2016) & 23 & $\mathrm{~F}$ & Chile & $\begin{array}{l}\text { Paternal Gilbert's syndrome; uncle died of } \\
\text { multiple myeloma. Syndrome polycystic } \\
\text { ovary. Taking oral contraceptive. No smoke, } \\
\text { no alcohol. }\end{array}$ & PEG precipitation \\
\hline Zhan et al. ${ }^{8}(2019)$ & 34 & $\mathrm{~F}$ & China & $\begin{array}{l}\text { No relevant family history. Infertile; mild } \\
\text { cholecystitis. Taking drugs for liver } \\
\text { protection and traditional Chinese medicine } \\
\text { for infertility. No alcohol. }\end{array}$ & $\begin{array}{l}\text { Refrigerated sample storage; Ig } \\
\text { depletion using protein A and G; } \\
\text { electrophoresis }\end{array}$ \\
\hline Ono et al. ${ }^{9}(2019)$ & 22 & $\mathrm{~F}$ & Japan & $\begin{array}{l}\text { No relevant family history. Common cold. } \\
\text { No taking medicine. }\end{array}$ & $\begin{array}{l}\text { GFC; refrigerated sample storage; } \\
\text { Ig depletion using protein A and } \\
\text { G; electrophoresis }\end{array}$ \\
\hline $\begin{array}{l}\text { González Raya et al. } \\
\text { (2019) }\end{array}$ & 50 & $\mathrm{~F}$ & Spain & $\begin{array}{l}\text { No relevant family history. Asymptomatic. } \\
\text { No alcohol, no drugs. }\end{array}$ & PEG precipitation \\
\hline Mingju et al..$^{11}(2020)$ & 48 & M & China & $\begin{array}{l}\text { No relevant family history. Mild fatty infiltration } \\
\text { of the liver with a small cyst. Asymptomatic. } \\
\text { Taking bicyclol, diammonium glycyrrhizinate } \\
\text { and Chinese herbs. }\end{array}$ & Ig depletion using protein $A$ and $G$ \\
\hline Sharma et al. ${ }^{12}$ (2019) & 46 & $\mathrm{~F}$ & USA & $\begin{array}{l}\text { Liver biopsy findings of steatohepatitis. } \\
\text { Asymptomatic. }\end{array}$ & PEG precipitation \\
\hline $\begin{array}{l}\text { Lartigau-Roussin et al. } \\
\qquad(2017)\end{array}$ & 45 & $\mathrm{~F}$ & France & $\begin{array}{l}\text { Appendectomy and depression; IgA myeloma; } \\
\text { autoimmune thyroiditis; telangiectasias } \\
\text { of the torso and back. Not taking therapy. } \\
\text { Smoking and moderate alcohol. }\end{array}$ & GFC; immunofixation \\
\hline Chtioui et al..$^{14}(2010)$ & 32 & $\mathrm{~F}$ & Switzerland & $\begin{array}{l}\text { No relevant family history. Acute EBV infection. } \\
\text { Asymptomatic. Taking oral contraception. }\end{array}$ & $\begin{array}{l}\text { Ig depletion using protein } \mathrm{A} \text { and } \mathrm{G} \text {; } \\
\text { refrigerated sample storage }\end{array}$ \\
\hline $\begin{array}{l}\text { Krishnamurthy et al. } .^{15} \\
\text { (2009) }\end{array}$ & 66 & $\mathrm{~F}$ & USA & $\begin{array}{l}\text { Chest discomfort and dyspnea. No taking } \\
\text { medicine. Moderate alcohol. }\end{array}$ & Ig depletion using protein $A$ and $G$ \\
\hline Mbagaya et al..$^{16}(2015)$ & 44 & $\mathrm{~F}$ & UK & $\begin{array}{l}\text { Epilepsy diagnosed at } 12 \text { years; constant } \\
\text { widespread pain affecting limbs and trunk; } \\
\text { poor sleep, irritable bowel and fatigue; } \\
\text { not connective tissue disorder. Taking } \\
\text { lamotrigine and sodium valproate. }\end{array}$ & PEG precipitation; GFC \\
\hline
\end{tabular}

No abnormality was reported in cardiac, abdominal, blood and serological tests (viral hepatitis B, C, A, Epstein-Barr virus, cytomegalovirus, and human immunodeficiency virus) as well as no fever, no myalgia, no jaundice, no night sweats, no weight loss, no pain or weakness in all patients. Therapy assumption has been reported.

macroAST, macro-aspartate aminotransferase; F, female; HBV, hepatitis B virus; Ig, immunoglobulins; PEG, polyethylene glycol; FANS, nonsteroidal antiinflammatory drug; GFC, gel filtration chromatography; M, male; EBV, Epstein-Barr virus. 
and there is heterogeneity of the macroAST molecule due to the different types of Ig or other plasma components. ${ }^{8}$ Finally, the PEG precipitation, described above, unlike the latter more complicated techniques, is a simple and low-cost method, which is commonly used for the detection of macroprolactin, ${ }^{5}$ possible in most routine laboratories and can be used for the screening of macroAST, giving a diagnosis in a short period of time. This method, however, has some limitations, like the possibility of interference with some assays, low specificity and the fact that an increase in serum globulins can lead to false positive results, as shown for macroprolactin. ${ }^{6}$

Also, as shown in this case report, the fruitful cooperation and clear communication between clinicians and the clinical laboratory can lead to the early and correct diagnosis of macroAST, avoiding diagnostic confusion and unnecessary, time-consuming, expensive and even invasive investigations., ${ }^{3,6}$

\section{Authors' contribution}

Maria Lorubbio wrote the manuscript. Agostino Ognibene, Benedetta Salvadori, Alessandra Fanelli and Giacomo Laffi critically re-viewed the manuscript. All authors participated in final approval of the manuscript.

\section{Acknowledgements}

The authors would like to thank Professor Fabio Marra, MPhil for correction of the English.

\section{Conflicts of Interest}

The authors have no conflicts to disclose.

\section{REFERENCES}

1. van Wijk XMR, Magee CA, Wu AHB, Tana MM, Lynch KL. A comparison of methods for evaluation of a case of suspected macroaspartate aminotransferase. Clin Chim Acta 2016;463:1-3.

2. Rubin AS, Sass DA, Stickle DF. Distribution of serum concentrations reported for macroenzyme aspartate aminotransferase (macro-AST). Pract Lab Med 2017;8:65-69.
3. Wener RR, Loupatty FJ, Schouten WE. Isolated elevated aspartate aminotransferase: a surprising outcome for clinicians. Neth J Med 2012;70:136-138.

4. Lee $M$, Vajro P, Keeffe EB. Isolated aspartate aminotransferase elevation: think macro-AST. Dig Dis Sci 2011;56:311-313.

5. Olukoga AO, Kane JW. Macroprolactinaemia: validation and application of the polyethylene glycol precipitation test and clinical characterization of the condition. Clin Endocrinol (Oxf) 1999;51:119-126.

6. Patteet L, Simoens M, Piqueur M, Wauters A. Laboratory detection of macro-aspartate aminotransferase: case report and evaluation of the PEG-precipitation method. Clin Biochem 2012;45:691-693.

7. Bustamante V, Arab JP, Terc F, Poggi H, Goycoolea M, Arrese M, et al. Persistent elevation of aspartate aminotransferase (AST) due to the presence of macro-AST: report of one case. Rev Med Chil 2016;144:1078-1082.

8. Zhan MR, Liu X, Zhang MY, Niu JQ. Isolated elevated aspartate aminotransferase in an asymptomatic woman due to macro-aspartate aminotransferase: a case report. World J Clin Cases 2019;7:44144419.

9. Ono S, Kurata C, Nishimura N, Kawashima H, Yoneima R, Tai Y, et al. Importance of laboratory detection of macro-aspartate aminotransferase. Int J Gen Med 2019;12:433-436.

10. González Raya A, Coca Zúñiga R, Martín Salido E. Isolated elevation of aspartate aminotransferase (AST) in an asymptomatic patient due to macro-AST. J Clin Lab Anal 2019;33:e22690.

11. Mingju H, Minyu W, Xiaoxiao G, Sumei L, Jianping M, Wanshan M. Macro-aspartate aminotransferase syndrome: a case report. Clin Chem Lab Med 2020;58:e96-e99.

12. Sharma N, Darr U, Darr A, Sood GK. Macro-aspartate aminotransferase: misleading finding in a patient with non-alcoholic fatty liver disease. Cureus 2019;11:e5042.

13. Lartigau-Roussin C, Paclet MH, Audin H, Toussaint B, Henni T, Raffray L. Macro-AST and myeloma: an incidental association? Rev Med Interne 2017;38:210-213.

14. Chtioui H, Mauerhofer O, Günther B, Dufour JF. Macro-AST in an asymptomatic young patient. Ann Hepatol 2010;9:93-95.

15. Krishnamurthy $S$, Korenblat KM, Scott MG. Persistent increase in aspartate aminotransferase in an asymptomatic patient. Clin Chem 2009;55:1573-1575.

16. Mbagaya W, Foo J, Luvai A, King C, Mapplebeck S, Gough A, et al. Persistently raised aspartate aminotransferase (AST) due to macroAST in a rheumatology clinic. Diagnosis (Berl) 2015;2:137-140. 